\title{
Planting Base Value of Hardworking Character Education through Ulid Novel
}

\author{
Hidayat Nur Septiadi ${ }^{1}$, Andayani ${ }^{2}$, Nugraheni Eko Wardani ${ }^{3}$ \\ ${ }^{1,2,3}$ Postgraduate of Sebelas Maret University, Indonesia \\ hidayatnurseptiadi28@gmail.com
}

\begin{abstract}
Important hard work characters are taught for the younger generation today so that researchers are interested in describing and explaining the values of character education in hard work in Ulid's novel by Mahfud Ikhwan. This novel tells the story of the struggle of poor families to send their eldest children from kindergarten to high school with various struggles and hard work in his life. The actions that the characters to bring out the character values of hard work that are proven through the attitude and every dialogue of the characters. This study included descriptive qualitative with note-taking techniques and literature studies. The results of data analysis of hard work character values are known to 9 frequencies, including unyielding characters, passionate characters, active working characters, earnest characters, the full character of confidence in acting, the full character of the struggle for life, independent practice character, cooperative character, and characters fight together.
\end{abstract}

Keywords : character education value; Ulid's novel; hard work character

\section{Introduction}

One of the forms of national character is marked by the formation of the character of its citizens. If people have good character, the nation will also have a good character. Character formation can be taught from an early age through the most basic education, namely kindergarten (nursery school). Megawangi (2009: 5) states that character education is an effort to educate children to be able to make wise decisions and practice them in daily life so that they can make a positive contribution to their environment. Berkowitz (2007: 30) also states that character education targets the character of child development which is a combination of psychological characteristics to motivate children and functions as an effective moral agent that is having a social attitude and hard work character.

Students should be introduced from the beginning regarding character education to shape their character. The character of children today is strongly influenced by technological advancements and daily interactions. For now, children easily access mobile phones and the internet. The school environment is the first place for character building, many factors influence this. Kapur explained in his article entitled "Factors Influencing the student's academic performance in secondary schools in India" which discussed education is very important for the advancement of individuals, communities, and nations. There are several factors that influence this, including factors in school and outside school. The school includes professionalism, the provision of library facilities, laboratories, the right teaching and learning process, well-structured teaching strategies, the use of technology, effective communication between students and instructors, and the important thing is the ability of teachers to deliver the material. Other factors that affect outside the school include the home environment, family harmony, and ways of the community.

In line with the above, Pietig in his article entitled "John Dewey and Character Education) also explained that character education applied in American public schools was based on John Dewey's idea of character education. Character education programs are aimed at developing goodness for students. Character education adheres to all objectives, and habits that affect student behavior. Having kindness means being able to get along well with other 
people. Dewey wants the school to provide students with opportunities for cooperation, selfdirection, leadership from obedience, activity, and actions that can train students hard work.

Various negative effects can be raised from the progress of the internet, the first impact can make children as consumptive individuals (internet addiction). Almost all information can be obtained from the internet, around school information, general information and even various types of games (games) are easily accessible. This resulted in children lingering on the internet for a long time, thus giving rise to consumptive and influential attitudes towards the internet. A little bit directly open the internet, as a result, can make a person who has minimal creativity.

Today many children, when ordered by their parents, argue, because they are playing with their cellphones or gadgets. The family environment must pay attention to the actions of their children to stay awake. The good and bad influence of the internet is determined by internet users, the role of teachers in schools is very much needed to direct their students to use the internet wisely. Not only at school, but the role of parents is also very much needed in supervising their children using the internet. Parents must be careful about monitoring their children. The role of parents is needed at all times to keep it from bad information.

The second impact can cause children difficult to socialize. When a child is absorbed in playing with his gadget, he will often forget time. This can be proven when children play games on gadgets for hours and hours so that children rarely leave the house. It's not good if children are engrossed in cyberspace. In the real world, children will feel indifferent to their surroundings. The internet can get close to the distance and can keep away from being close. By playing games children are free to meet anyone in the virtual world because that attitude can cause ignorance with friends in the world in fact.

The third impact can cause students to be lazy to learn. Students have no days without accessing inter with their gadgets. When students are instructed to learn by their parents the answer is later, later, and later. That's because it's fun playing the gadget. Over time can form a lazy person to learn because it is inversely proportional to the achievements he achieved. Children who are lazy to learn are definitely low. Parents can overcome this problem by limiting the use of the internet every day. Children are directed to access informationinformation related to their subject matter. This is confirmed by the research conducted by Ahmed in his article entitled "Moral Learning Outside the School: an Overview"discussing moral education focused on teaching moral values. Today's modern era has resulted in youth's tendency towards western style and culture. Parents emphasize overall child development education. Not only are parents alone the teacher is also responsible for directing the education of their students. At school teachers are responsible for instilling human values in their students. Likewise, at home, parents are expected to teach behaviors that reflect character education. Teachers and parents together carry out their duties to teach character values. Character education is taught not only at school even in the family environment, but the community environment must also be taught from an early age to form a good personality.

Character education of hard work can be taught through a variety of ways, one of which is through literary works, because literary works are an expression of all thoughts, ideas or ideas that are expressed in the form of literary texts. Nurgiyantoro (2013: 434) revealed that literature has a role as an educational tool that should be utilized in the world of education, literature is focused on the role to shape children's personality/character building.

Planting character education for students can go through several literary genres more precisely is fiction. Lately, the work of fiction that is currently popular is novel. Novels offer a variety of human, humanitarian, life and life problems. The author lives the various problems with a sincerity which he then expresses again through means of fiction in the form of novels 
in accordance with his views. The novel is a type of literary work written in narrative form and contains certain conflicts in the life stories of the characters in the story. Novels are usually referred to as literary works that tell a part of one's life. Wardani (16: 2009) reinforces that novels are fictions that reveal stories about characters, and contain stories about characters who experience problems in the world and try to find authentic values in their world.

Researchers are interested in examining the works of writers who speak about the social life of small people in Indonesia, the author is Mahfud Ikhwan. One of the novels is Ulid. Ulid's novel tells the story of the struggle of a poor family to keep sending their children from childhood starting from kindergarten (TK) to graduating from high school (SMA). The little boy was named Muhammad Maulid, or often called by his famous name Ulid. This novel is set in a remote village called Lerok, in East Java. Ulid was born to a poor family. His father worked as a teacher and farmer. Ulid's father named Tarmidi. After finishing teaching at the Ibtidaiyah Madrasa, he rushed to the forest to look for wooden chunks to be used as material for burning stoves and there were still many more interesting stories. Ulid's novel contains character education, one of which is the character value of hard work. Ulid's novel is a winning novel of the DKJ (Jakarta Arts Council) competition in 2014 published by Pustaka Ifada in 2016. In this study, the study of literary works is focused based on character figures, especially the character of psychologically hard work. The researcher explained and described the values of character education hard work in Ulid's novel that was reflected in the dialogue of figures.

\section{Review of Literature}

\subsection{Value of Character Education}

Megawangi (2009: 5) states that character education is a conscious effort carried out by educators to students so that they can make decisions on character values in terms of goodness, and practice it directly in school, at home, and in daily life, so that they can make a positive contribution to the environment. In addition, Schaps and Lewis (1997: 215) conceptualize character education as instruction that seeks the development of citizens, caring, principled, and responsible. The importance of fostering character education in oneself so that in the future it will be better to achieve a perfect goal. In line with this, Lickona (2016: 74-84) also conceptualizes the value of character education with regard to moral knowledge, moral feeling, and moral behavior. Moral knowledge includes moral awareness, knowledge of moral values, knowledge of perspectives, moral thinking, decision making, personal knowledge. Furthermore, moral feelings include conscience, self-esteem, empathy, loving good things, self-control, humility. Of the two exposures created a moral action including competence, desires, and habits.

\subsection{Value of Hardworking Character Education}

The value of character in relation to oneself is one of them is hard work. Elfindri (2012: 102) argues that hard work is the nature of someone who is not easily discouraged accompanied by a strong will in trying to achieve goals and ideals. In line with this, Yaumi (2014: 94) also argues that hard work is a behavior that shows genuine effort in overcoming various obstacles to learning and assignments and completing tasks as well as possible.

\subsection{Character Education in Novels}

Good literary works contain good values to be conveyed to the reader. These values are able to build the character of a person especially students. Nurgiyantoro (2005: 321) states that 
a work of fiction was written by the author to offer an idealized model of life. Fiction contains the application of morals in the attitudes and behavior of the leaders in accordance with their views on morals. Through stories, attitudes, and behaviors of those figures, readers are expected to be able to take lessons from moral messages that are conveyed or mandated. In line with this, Semi (1993: 18) also states that literature always plays a very important role, because it almost always expresses human values, because the nature of literature is not normative, then literature can communicate more easily so that the values conveyed easier to digest.

\section{Research Methods}

This study included qualitative descriptive research. This form of research is used to describe the state of the object under study and describe the aspects that are the center of attention in the study. The researcher aims to describe and explain the value of character education as hard work as the object of study. The method used in this study is content analysis with a literary psychology approach and the hard work values of character education contained in the novel.

Creswell (2010: 243-270) states that the technique of data analysis is the process of arranging data sequences by classifying them into patterns, categories, and basic units of description. This study analyzed the data using flow model analysis techniques. There are several steps in the flow analysis of data models according to Miles and Huberman (2012: 1519), namely (1) data reduction, is the activity of collecting data and grouping data based on the problems studied. The data taken is in the form of words or sentences taken in the Ulid novel by Mahfud Ikhwan to reveal information that refers to the problems taken in this study. Ulid's novel was published by the Ifada Library in 2016 as many as 535 pages; (2) data presentation, carried out after data reduction through the stages of describing and explaining the values of hard work character education contained in the novel Ulid; and (3) drawing conclusions, carried out after data reduction and data presentation. The researcher describes and explains the important meaning of the data that has been collected.

\section{Results and Discussion}

In the Ulid novel, several studies have been found that reflect the value of hard-working character education, including (1) unyielding character; (2) a character full of enthusiasm; (3) characters actively work; (4) serious character; (5) a character full of confidence in acting; (6) full character of struggle to keep up; (7) characters practice independently; (8) the character of cooperation; and (9) characters fight together.

\subsection{Characters Never Give Up}

Ulid is an unyielding figure when ordered to bring a wooden branch larger than his body. The example in the quote below:

"The little one receives happily. The branch was grabbed by him as he ran around the dog following his old mother. It was done many times. Every now and then, again he whined asking for bigger wood. He said, he was ridiculed by Yamin, the youngest Wali son, who was two years older than him because he only had strong branches". 
"Even though he never really objected to the wood he was carrying, the distance where the wood was hidden was enough to make his sweat run down on the same day". (U, 2016: 8)

The above quote is an example of the unyielding character displayed by Ulid. He helps his mother happily without any coercion. Even though Ulid's body was still small, he still tried to bring branches that exceeded his body by running around. Basically, a child of the age of Ulid still likes running around doing things, because what he does with a sincere heart is to help his mother. He even asked for a bigger branch. When he really objected to carrying the wood, sweat had poured in his face. Ulid continued to finish his task at home. This shows that Ulid's attitude reflects the unyielding character of helping his mother to bring wood even though the wood is bigger than his body. Ulid's mirrored unyielding character can be taught and instilled by the teacher towards his students when learning literature through action in the story dialogue.

\subsection{Character Full of Passion}

In addition to unyielding character, Ulid is also a person who is full of enthusiasm for helping his parents. The following excerpts and explanations are related to the discovery of a passionate character.

"The loose wood was dismantled. The bound wood is carried directly with the rope. Larger logs must be transported one by one. Sir, am I coming? The little one doesn't want to lose. Sir? He urged-exactly whining. Either because he feels compassion and wants to help or because he sees the busyness of the adults as something exciting".

"Do not have to! said the father harder while still dismantling the wood to transport his wife. Got a scorpion, cured later! But your little one has pushed. Look, he was so eagerly trying to drag a teak stem that was bigger than his body. Of course, nothing moves, except for the lip part that sticks out because it is so hard he tries". (U, 2016: 8)

The above quote is an example of the vigorous character displayed by Ulid. He always wanted to help bring the wood that had been collected by his father. Even though he was warned by his father but the desire to help him was very great. Pieces of teak wood heavier than his body did not make Ulid feel heavy even he eagerly took him to get home. This was reflected through the movement of his lips which were sticky when carrying the teak wood part with enthusiasm on his way home.

\subsection{Strict Working Character}

Tarmidi is a figure who actively works in collecting stones and wood for fuel. The following quotes and explanations related to the discovery of characters actively work.

"If the fire is so loyal to always bring together stones, wood, and links to become a very good host for the meeting. With great patience, Tarmidi took care of the fire. The next wood chips are still being pushed, then the hardened branches are even harder. Then, the crackling of the flames began to echo and the puff of smoke at the peak of the surge increased. Furthermore, it starts to blacken. One of the two exploding rock sounds was heard". (U, 2016: 28) 
The above quote is an example of the active character of work displayed by Tarmidi. After collecting stones, wood, and connecting later he prepares a fire to start burning it. With high patience, slowly Tarmidi lit the fire through wood chips that he had prepared first. He took care of the fire by continuing to put dry wood to keep the fire burning. We already know that making a big fire is not easy, but with great perseverance and patience, Tarmidi is able to do it. It can be instilled in the young generation when doing something must be persistent and practice patience for something they want. Slowly what has been done will suit the purpose.

\subsection{Characters are serious}

Ulid is also a figure who is serious in carrying out actions. This is illustrated in the quote below:

"Sir, i was burned, i heard a shrill little voice. He ran with plastic with small food, overtaking his mother who was behind carrying food. Today is Friday, the little one is off kindergarten school. Kaswati can cook early. Yes, Sir. Once again the little one asked for his steps to reach his father's back. What? Burn my heart too. He shows his little contact. He said he wanted to burn himself? "

"After eating, Tarmidi was forced to obey his son's request. The little contact was briefly then followed by steaming. The little one is so excited. Sir, the smoke starts black. Sir, can't I put it in? he shouted passionately as he brandished a piece of wood root to his father. He then put it in the mouth of his small connection with a very earnest face". (U, 2016: 28-29)

The above quote is an example of the earnest character displayed by Ulid. Although Ulid was still in kindergarten he practiced making small chains and burning them with wood chips. He asked his father for help to burn him beforehand. When the fire was on, Ulid slowly inserted one by one fragments of wood then came out the black smoke. The small Ulid connection does not stop him from seriously practicing burning the contact. With the frequency with which he practiced, he smoothed himself out. The earnest character can be instilled in the young generation, when doing something start from the small things first, slowly the small things will develop and become big.

\subsection{Character Full of Confidence in Acting}

Ulid is a figure full of confidence in acting to help his parents pick fruit from yam in his father's garden. This is illustrated in the quote below:

"First withdrawal, Ulid succeeded. He proudly showed the results of his pull: a big and round jug. He loudly called out, as if he wanted the whole world to hear, that he could indeed pull out the yam. Look at this, sir! His left hand once again showed off to the world the results of his pull. While his right hand was high like a commander raised his sword in front of thousands of his soldiers".

"The second pull, with some difficulty he succeeded. The jellies are slightly scratched in one part. He then thrust the lever back. This time it's more uplifting". (U, 2016: 47)

The above quote is an example of a character full of confidence in acting that is displayed by Ulid. Need to be explained first, yam is a creeper about 20 meters high, the leaves are tapered, white tuber, the skin is easily peeled, tastes sweet, and contains a lot of water. Ulid 
helped his father to pull out one by one the yam in the field with confidence. Slowly gathering lots of swelling. He showed his father that Ulid helped his father with confidence. He is always excited from the first, second, and so on. The behavior carried out by Ulid in dialogue can be instilled in students so that in acting must be full of confidence whether in learning activities at school, at home or acting in their daily lives.

\subsection{Full Struggle Characters for Life}

Lerok woman is a struggling woman in her daily life. Not only at home but they also have a big role in the fields. This is illustrated in the quote below:

"Talking about Lerok women is talking about great creatures. They are not only mothers for their children, wives of their husbands, but also the frightening conquerors of Lerok. No big woman in Lerok is comfortable if she only dwells in the house and kitchen".

"They are not meant for that. Although the lerok generally view that the burden of absolute living is piled up on men, the Lerok women are almost involved in all existing and possible work in Lerok. It can be said, there are no jobs, both in the fields, in the forest, on the hills, also on the links, which do not involve women". (U, 2016: 176)

The above quote is an example of the full character of the struggle for life carried out by Lerok women. It needs to be explained in advance that Lerok is a remote village in East Java which is the setting in this novel. Lerok women are very eager to always fight in their daily lives. They don't just struggle at home and the kitchen. After they finished cooking for their husbands and children, they rushed to the fields to check the yam and there were also those who were looking for chunks of wood to be used as fuel for joints. They always struggle to help her husband. The attitude described by Lerok women can be exemplified and taught to the younger generation, especially girls who are still in school. After returning home they were implanted with characters struggling to help their mothers, maybe just helping in the kitchen or in the rice fields is not the most important problem is that they have been introduced to the character of hard work.

\subsection{Characters Practicing Mandiri}

Ulid also has a figure practicing independently in his daily life. This can be displayed through the quote below:

"He kept looking for firewood. Looking for firewood, regardless of the fact that the boiled cassava is less and less. Look for firewood regardless of whether the wood has piled up so much. So like the previous afternoons, he arrived from school, took off his uniform, then offered the dhuhur prayer, then nothing else was said by Ulid other than, I was looking for wood, Mak!”. (U, 2016: 221)

The above quote is an example of the character of independent practice as reflected by Ulid. When he returned home from school he took off his own uniform, after that the dhuhur prayer and rushed to look for wood in the forest. Ulid's attitude reflected that he was after school not lazing at home but he was always eager to find wood to take home. In addition to burning the bridge, the wood can also be used by the mother for cooking fuel in the kitchen. This can be taught and instilled in kindergarten students for after school to help their parents without reducing their obligations. If the child from the farm family can help the father or 
mother in the field. There is more from the family of food vendors that children can be taught to help their parents in a shop do things that can be done according to their abilities.

\subsection{Character of Cooperation}

Ulid and his friend Pi'i are people who can work and work together. This can be illustrated in the quote below:

"Ulid and Pi'i who work together to build connecting walls are more touching. Their bodies and faces which can no longer be distinguished from the connecting wall they build represent a complete selfless surrender. Their hands are so busy, between the stones, the soil mixture, then the soil mixture, then the stone again, and then sweat on their faces. Their mouths stop shouting what they need. Occasionally Pi'i or Ulid stand up, back away, slightly away, then look sharply at the building that is being erected, nodding for a while, and usually closed by throwing the remaining mud dough hard in the hand to the connecting wall". (U, 2016: 227)

The quote above is an example of a joint character that is displayed by Ulid and Pi'i they shoulder to shoulder to build a connecting wall. Their bodies and faces have mixed with the color of the wall and cannot even be distinguished between their faces and the wall. All members of their existing body use as much as possible, their hands to do the mixture between the rock and the ground. They are not afraid of being dirty in order to realize the desired wall. This reflects that Ulid and Pi'i both tried together to make a wall. Heavy work when done together will feel light. The attitude raised by Ulid and Pi'i can be an example for students when doing something. For example, there are school assignments from the teacher. Students are instilled with characters trying to work together on these questions by discussing forming groups. In addition to training the sensitivity of one student to another, the character of trying together can also establish harmony.

\subsection{Joint Fighting Characters}

Ulid, his father, named Tarmidi, and his mother, Kaswati, are hard-working people who make a living for their family's needs and attend to their younger siblings Ulid. This can be illustrated in the quote below:

"Although both in Malaysia, Tarmidi, Kaswati, and Ulid did not gather together. Kaswati who works as a housemaid lives in her employer's house. Tarmidi and Ulid, even though they are building jobs, work in different places and therefore live separately. The three of them only met when they came together. Fastest once a month. The three of them can gather a little longer if Chinese Eid comes. The family usually met in the village of Pandang, precisely in the house belonging to his wife Pi'i, which was usually used as a meeting place for Lerok people overseas". (Ulid, 2016: 522)

The above quote is a joint fighting character displayed by the Ulid family. Her mother is a housemaid, her father who works like Ulid in a building but the place is different. They did this to still be able to support their families and send their younger siblings Ulid to school. The attitude reflected by the Ulid family is very good to be instilled in today's young generation. When parents have struggled to find work to send their children to school, it is good and should be taught as a child to respect their efforts by being serious in school to carry out their obligations. When the children they have fought together to get achievements are certainly 
proud of their parents and siblings. The character of fighting together should be introduced to students to work hard in school. Parents have tried their best to be able to send their children to school, as well as the children who are fought must have an attitude of respect for their parents by diligently going to school, being serious in doing things, which is very important to keep their worship.

\section{Conclusion}

Based on the results of the analysis described and explained in this study, the character education of hard work is very important to be taught and instilled in the younger generation. Character education hard work aims to be active and enthusiastic in learning. In addition, it is expected to develop self-potential, both in the form of talents, interests, knowledge, and skills possessed by the young generation today.

Hard character education is expected to form a disciplined person, responsible for everything, not easily discouraged both in the school environment, community environment, and daily life. The value of hard work contained in Ulid's novel by Mahfud Ikhwan includes unyielding characters, energetic characters, active working characters, earnest characters, a character full of confidence in acting, a character full of struggle for life, a character full of struggle for life, a practicing character independent, cooperative character, and characters fighting together.

\section{References}

Berkowitz, M.W., and J. H. Grych. (1998). Fostering Goodness: Teaching Parents to Facilitate Children's Moral Development. Journal of Moral Education 27:371-91.

Creswell, J.W. (2010). Research Design: Pendekatan Kualitatif, Kuantitatif, dan Mixed. Yogyakarta: Pustaka Pelajar.

Elfindri. (2012). Pendidikan Karakter: Kerangka, Metode, Dan Aplikasi Untuk Pendidikan dan Professional. Jakarta: Baduose Media.

Ikhwan, Mahfud. (2016). Ulid. Yogyakarta: Pustaka Ifada.

Kapur, Radhika. (2018). Factors Influencing the Students Academic Performance in Secondary School in India. University Of Delhi.

Kumar, Ashok and Ahmed Shabir. (2016). Moral Learning Outside the School: An Overview. North Asian International Research Journal of Multidisciplinary. 2 (12), 1-10.

Lickona, T. (2016). Educating for character. Mendidik untuk Membentuk Karakter.Terj. Juma Wadu Wamaungu. Jakarta. Bumi Aksara.

Megawangi, Ratna. (2009). Pengembangan Program Pendidikan Karakter Di Sekolah: Pengalaman Sekolah Karakter. Depok: Indonesia HeritageFoundation.

Miles, M.B and Huberman,A.M. (2012). Analisis Data Kualitatif. Jakarta: UI Press

Nurgiyantoro, Burhan. (2013). Teori Pengkajian Fiksi. Yogyakarta: UGM Press.

Pietig, Jeanne. (2006). John Dewey and Character Education. Journal of Moral Education. 6 (3), 170-180.

Schaps, E., and Lewis,C. (1999). Perils on an essential journey: Building school community. Phi Delta Kappan, 81(3), 215-218.

Wardani, Nugraheni Eko. (2009). Makna Totalitas dalam Karya Sastra. Surakarta: UNS Press.

Yaumi, Muhammad. (2014). Pendidikan Karakter: Landasan, Pilar dan Implementasi. Jakarta: Prenada Media Group. 